解 説

\title{
GLIOを用いたグローバル環境負荷原単位データベースの開発
}

南斉 規介・近藤 康之・加河 茂美

\section{Database Development of Embodied Global-environmental-burden Intensities for Japanese Products with GLIO}

Keisuke NANSAI, Yasushi KONDO and Shigemi KAGAWA

\section{1.はじめに}

1990年比で温室効果ガス（GHG: Greenhouse gas）排出 量の $6 \%$ 削減を国際的責務として日本が負った京都議定書 の第一約束期間が 2012 年末を以って終了した。第一約束

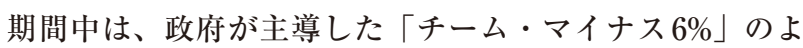
うに、国内排出量の削減を中心に取り組んできたが、昨今 では削減や管理の対象とすべき排出量の範囲（システム境 界）が大きく変化している。例えば、製品レベルではカー ボンフットプリントの本格的な運用が開始され、環境フッ トプリントへの対応に向けた検討も動き出している。一方、 企業レベルでは、GHGプロトコルやISO (International Organization for Standardization) によるスコープ3や組 織のカーボンフットプリントが国際的な注目を集めている。 日本でもそのガイドライン作りが行われている。これらの 国際規格の特徵は、LCAでは当然の考え方であるが、製 品の生産や企業活動に伴う GHGというものを、生産現場 や企業内で生じる排出（直接）に限定せず、そのサプライ チェーンを通じて誘発する排出（間接）を含めて考え、排 出量の管理・削減を広く促進することである。今や「純国 産」と言っても、そのサプライチェーンを遡れば日本国内 で完全に閉じることはなく、何らかの輸入品の利用を通じ て国外の生産プロセスと繋がっている。これは、管理すべ き排出量の範囲も必然的に国内だけに留まらないことを 意味すると同時に、京都議定書では「マイナス $6 \% 」 の$ 対 象外であった国外での排出を含めて管理することで、排出 量の新たな削減機会を見出すことが可能となったと理解 できる。

LCAのインベントリ分析は、上述のようなサプライ チェーンを遡及する排出量の把握には最も適した方法論で あり、日本では積み上げ法だけでなく産業連関分析法の適
用も数多くみられる。産業連関分析法の利点として、イン ベントリ分析におけるシステム境界の明確さや、『産業連 関表による環境負荷原単位データブック（3EID）』（南斉、 森口）や中野ら（2008）のように、公開されている部門別 の内包型原単位（単位生産あたりの直接間接の排出量）を 利用することで、データ収集に掛る労力を軽減できること があげられる。しかし、日本でLCAに産業連関分析法が 活用される最大の理由は、日本の産業連関表が米国に次い で詳細な部門分類で作成されており、約 400 の部門分類で 財やサービスに関する内包型原単位が利用できるからであ ろう。仮に日本の産業連関表が欧州のように 60 部門程度 しかなければ、一つの部門に多くの財やサービスが集約さ れてしまうため、内包型原単位の不確実性への懸念から LCA での利用は極めて限定的であったと想像される。

一方、削減に向けて注力すべき排出が国内から国内外へ と軸足を移動するにつれ、従来の内包型原単位を利用する ことが不適切な事例が増加する。例えば、3EIDでは(1)輸 入品を控除して国内排出だけを含む内包型原単位（3EID では $\left.(\mathrm{I}-(\mathrm{I}-\mathrm{M}) \mathrm{A})^{-1}\right)$ 型と表記) と(2)輸入品を含むがその 生産プロセスは国産品と同等とみなす内包型原単位 (3EID では $\left.(\mathrm{I}-\mathrm{A})^{-1}\right)$ 型と表記）の二種類が提供されている。し かし、前者は国外排出を全く計算できず、後者も国産技術 仮定という強い仮定に基づくため、利用にはその妥当性を 検証する必要がある。国内外の排出量の算定に際し、仮に デー夕整備に係るコストを無視し得るとすれば、最も適切 な方法は多地域間産業連関表（MRIO: Multi-regional input-output table）による内包型原単位を利用すること である。グローバルに広がるサプライチェーンの実態を鑑 みると、国外排出量を網羅的に捉えるには、世界のあらゆ る国や地域を含むMRIOであることが望ましい。そして何 
よりも、約 400 の部門分類に基づき日本の財やサービスに 関する内包型原単位が導出できるMRIOであることが重要 である。しかしながら、MRIOの構築は一般的に国の数や 各国の部門数が増えると共に、その作成に掛る時間的・人 的コストは増大する。それゆえ、世界経済全体を対象とす るMRIOの多くは、各国の部門数を抑え、最大でも EXIOPOLの129部門である（タッカー 2013）。これでは、 日本の産業連関表の詳細性が生かせず、LCAでの活用を 妨げてしまう。日本の産業連関表の部門分類を生かしなが らも、世界全体を含むMRIOの構築を低コストで実行する 手段の一つとして、Eora（モランら 2013）のような作表手 続きの自動化が考えられる。もう一つは、MRIOの構造自 身を簡略化しデー夕整備の労力を軽減する方法である。筆 者らは、独自のMRIOの簡略化手法を考案し、GLIO (グリ オ) (Global link input-output model) (Nansai et al. 2009）と呼ぶ新しい産業連関モデルを開発している。本 稿では、典型的な MRIO簡略化の方法とその特徴を記述す るとともに、筆者らが開発したGLIOの構造とそれを応用 したグローバル内包型原単位の整備について紹介する。

\section{2. 世界を対象とした MRIOの簡略化手法}

\subsection{LCA に利用する理想的な世界 MRIO}

グローバルな環境負荷量を定量するための理想的な MRIO とは世界中の全ての国や地域が含まれており、財や サービスの種類が細かく定義されている表である。いま、 表1を理想的な環境分析用の MRIOとする。説明の簡略化 のために、最終需要や付加価值の記述は省略する。表 1 は 世界がA国、B国、C国の3か国で構成され、財とサービ スの 2 つ商品しか存在しない世界経済取引を描いている。 表の 1 行目から 6 行目の值は、年間の取引額 (ドル $(\$) /$ 年 $)$ を指し、列方向に見ることで、各国が商品を作るのに必要 な各商品（財とサービス）の購入額を知ることができる。 また、各商品の生産により発生した環境負荷量（この表で はGHG排出量）を読み取ることができる。

この表から A国の財の生産に必要な商品を確認する。A
国の財は自身の生産のために、A国の財を 1 ドル分を購入し、 A国のサービスを 7 ドル分を購入した。また、A国の財生 産のためにB国の財およびサービスをそれぞれ 13 ドル分、 19 ドル分を輸入して使用した。同様に、C国の財およびサー ビスを必要とし、それぞれ 25 ドル分、 31 ドル分を輸入し、 総額は 96 ドルであることが分かる。この表に記載されて いる取引額の合計は 666 ドルである。また、A国の財の生

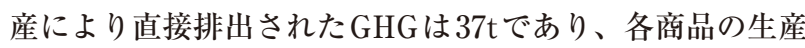
による直接排出量の合計は $237 \mathrm{t}(=37+38+39+40+41$ +42) である。

表1から、A国、B国、C国において財を生産するのに 必要な商品、サービスを生産するのに必要な商品の量が異 なることが明示的に理解できる。しかし、 $7 \times 6=42$ 力所 のデータポイント（取引額と排出量）を調査、推計する必 要があり、作表コストは高い。作表のコストを下げる手段 として、主に3つのアプローチが考えられる。各方法を簡 単に紹介し、利点と欠点を整理する。

\section{2 簡略化 1 : 商品区分の解像度を下げる}

一つ目は、複数の商品を統合して、部門分類の解像度を 下げることで部門数を減らし、作表のコストを下げる方法 である。例えば、表2のように、表1では区分されていた 各国の商品の財とサービスを統合し、統合商品 $=$ 財 +サー ビスを定義する。作表において推計すべきデータポイント は、 $4 \times 3=12$ 力所となり、表 1 のデータポイント数 42 と 比較すると $28.5 \%(=12 \div 42 \times 100)$ に相当し、作表の負担 が軽減される。

表2では、A 国の統合商品の年間の生産に必要な商品は、 A国の統合商品を 18 ドル $(=1+2+7+8) 、 \mathrm{~B}$ 国の統合 商品 66 ドル $(=13+14+19+20) 、$ C国の統合商品を 114 ドル $(=25+26+31+31)$ であることを示す。A国の統 合商品の生産による直接的な $\mathrm{GHG}$ 排出は $75 \mathrm{t}(=37+38)$ となる。この表に記載されている取引額の合計は 666 ドル $(=18+26+34+66+74+82+114+122+130) 、$ GHG 排出量の合計は $237 \mathrm{t}(=75+79+83)$ であり、簡易なが

表1 3つの国と2つの商品で構成される標準的な MRIO 構造

\begin{tabular}{|c|c|c|c|c|c|c|c|}
\hline & \multicolumn{2}{|c|}{ A } & \multicolumn{2}{|c|}{ B } & \multicolumn{2}{|c|}{$\mathrm{C}$} \\
\hline & & 財 & サービス & 財 & サービス & 財 & サービス \\
\hline \multirow{2}{*}{ A } & 財（\$） & 1 & 2 & 3 & 4 & 5 & 6 \\
\hline & サービス（\$） & 7 & 8 & 9 & 10 & 11 & 12 \\
\hline \multirow{2}{*}{ B } & 財（\$） & 13 & 14 & 15 & 16 & 17 & 18 \\
\hline & サービス（\$） & 19 & 20 & 21 & 22 & 23 & 24 \\
\hline \multirow{2}{*}{$\mathrm{C}$} & 財（\$） & 25 & 26 & 27 & 28 & 29 & 30 \\
\hline & サービス（\$) & 31 & 32 & 33 & 34 & 35 & 36 \\
\hline 排出 & GHG（t） & 37 & 38 & 39 & 40 & 41 & 42 \\
\hline
\end{tabular}


表2 商品区分を統合することで簡略化されたMRIO構造

\begin{tabular}{|cc|c|c|c|}
\hline \multirow{2}{*}{} & A & B & C \\
\cline { 3 - 5 } & 統合商品 & 統合商品 & 統合商品 \\
\hline A & 統合商品 $(\$)$ & 18 & 26 & 34 \\
\hline B & 統合商品 $(\$)$ & 66 & 74 & 82 \\
\hline C $\quad$ 統合商品 $(\$)$ & 114 & 122 & 130 \\
\hline 排出 & GHG $(\mathrm{t})$ & 75 & 79 & 83 \\
\hline
\end{tabular}

表3 地域区分を統合することで簡略化されたMRIO構造

\begin{tabular}{|c|c|c|c|c|c|}
\hline & \multicolumn{2}{|c|}{ A } & \multicolumn{2}{|c|}{ 統合国（B\&C） } \\
\hline & & 財 & サービス & 財 & サービス \\
\hline & 財 (\$) & 1 & 2 & 8 & 10 \\
\hline A & サービス（\$） & 7 & 8 & 20 & 22 \\
\hline 統合国 & 財 (\$) & 38 & 40 & 88 & 92 \\
\hline$(\mathrm{B} \& \mathrm{C})$ & サービス（\$） & 50 & 52 & 112 & 116 \\
\hline 排出 & GHG (t) & 37 & 38 & 80 & 82 \\
\hline
\end{tabular}

らも表 1 と等規模の世界経済を表現する。A、B、C国は明 確に区分されているため、例えば、国別のカーボンフット プリント分析など、国の違いに着目する分析には適してい る。その一方で、財とサービスの区別はできないため、製 品のLCAのような生産技術の違いを重視する分析には適 さない。

\section{3 簡略化 2 : 国の区分の解像度を下げる}

二つ目は、複数の国を統合して、部門分類の解像度を下 げることで部門数を減らし、作表のコストを下げる方法で ある。例えば、表 3 のように、表1では区分されていた $\mathrm{B}$ 国とC国を一国とみなして、統合国（B＆C）を定義する。 作表において推計すべきデータポイントは、 $5 \times 4=20$ カ 所となり、作表の負担は表 1 の $47.6 \%(=20 \div 42 \times 100)$ と なる。例えば、その他の国（RoW: Rest of the world）を 定義する OECD-ICIO (山野 2013)、WIOD (ディツェンバッ ハーら 2013)、EXIOPOL (タッカー 2013)、GTAP (ウォ ルムスリーら 2013）などはこの例に該当する。

表3では、統合国（B＆ C）の財の年間の生産に必要な 商品は、A国の財を 8 ドル $(=3+5) 、 A$ 国のサービスを 20 ドル $(=9+11)$ 、統合国 $(B \& C)$ の財を 88 ドル（=15 $+17+27+29)$ 、統合国 $(\mathrm{B} \& \mathrm{C})$ のサービスを 112 ドル $(=$ $21+23+33+35)$ であることを示す。統合国（B＆ C) の財の GHG排出は $80 \mathrm{t}(=39+41)$ である。この表に記載 されている取引額の合計は 666 ドル $(=18+26+34+66$ $+74+82+114+122+130) 、$ GHG 排出量は $237 \mathrm{t}(=75+$
$79+83 ） て ゙ あ り 、$ 表 1 と同等の世界経済を表現する。財と サービスの生産構造の違いは明確に区分されているため、 商品間の比較や製品のLCAへの適用は可能である。しかし、 $\mathrm{B}$ 国とC 国の個々の排出量は同定できないため、当然なが ら国別の分析には不適である。

\section{4 簡略化 $3:$ モ モ゙ルに含める国の数を減らす}

三つ目は、商品分類や国の部門統合をせず、単に考慮す る国の数を減らすことで、作表のコストを下げる方法であ る。例えば、表1では A、B、C国のそれぞれの生産構造、 すなわち各国の生産に必要な商品を記述するが、表4で A 国とB国のみを対象とし、C国内の経済活動の世界経済へ の作用を除外している。したがって、A国とB国のみを含 む（A国とB国で構成する $4 \times 4$ の行列部分からなる）産業 連関分析となるが、作表において推計すべきデータポイン 卜は、 $5 \times 4=20$ カ所となりとなり、作表の負担は表 1 と 比べ $47.6 \%(=20 \div 42 \times 100)$ と軽減される。この方法は、 特にC国に関する産業連関表と貿易に関する統計が得られ ない場合に有効である。アジア国際産業連関表（猪俣 2013）の MRIOはこの例に該当する。

表4では、A国、B国と国の区分、財とサービスの商品 区分が明確にされており、国の特徴、商品の生産技術の特 徵を反映した分析が可能である。すなわち、A国とB国の 国全体のカーボンフットプリントの比較や、A国の財と B 国の財を対象としたLCAにも対応できる。一方、C国を 除外しているため、この表に記載されている取引額の合計 
表4 一部の地域をシステム境界から除外することで簡略化されたMRIO構造

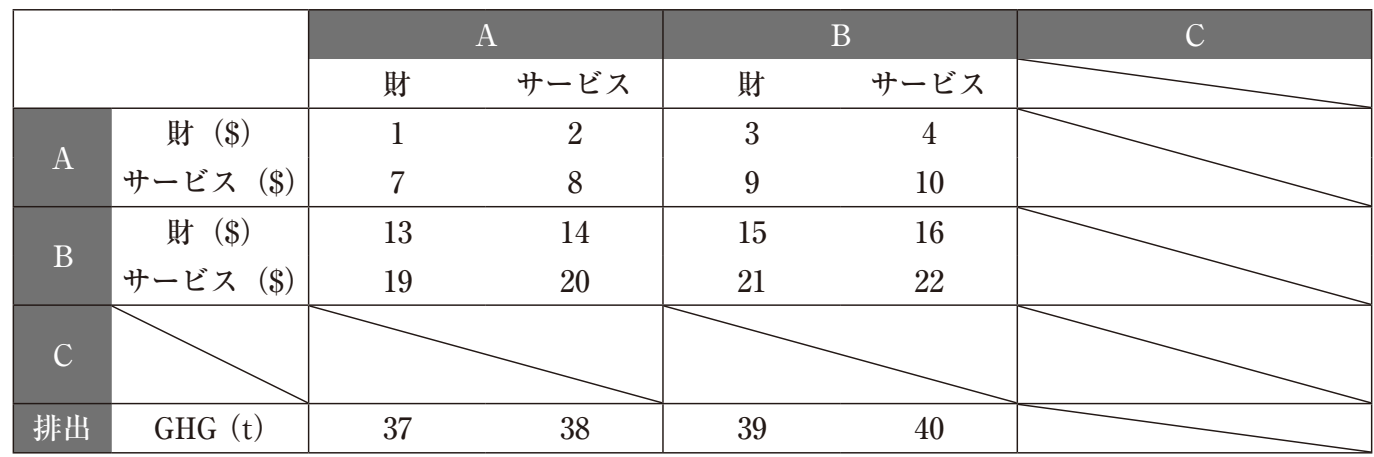

表5 GLIOの勘定体系に基づくMRIOの簡略化構造

\begin{tabular}{|c|c|cc|c|c|}
\hline \multicolumn{2}{|c|}{} & \multicolumn{2}{c|}{ A } & B & C \\
\cline { 3 - 6 } \multicolumn{2}{c|}{} & 財 & サービス & 統合商品 & 統合商品 \\
\hline \multirow{2}{*}{ A } & 財 $(\$)$ & 1 & 2 & 7 & 11 \\
& サービス $(\$)$ & 7 & 8 & 19 & 23 \\
\hline \multirow{2}{*}{ B } & 財 $(\$)$ & 13 & 14 & 31 & 35 \\
& サービス $(\$)$ & 19 & 20 & 43 & 47 \\
\hline \multirow{2}{*}{ C } & 財 $(\$)$ & 25 & 26 & 55 & 71 \\
\hline サービス $(\$)$ & 31 & 32 & 67 & 83 \\
\hline
\end{tabular}

は 184 ドル（表1では 666 ドル）、GHG排出量は $154 \mathrm{t}$ (表 1 では $237 \mathrm{t} ）$ であり、表 2 や表 3 の MRIOの簡略化とは異な る世界経済の範囲に基づく分析となる。そのため、A 国、 B国の各商品の生産において、C国からの輸入品が多い場 合やC国の世界に占める GHG排出量の割合が高い場合には、 A 国、B国のカーボンフットプリントや製品のLCAの值 は実態よりも過小評価される。

\section{GLIO(グリオ) の簡略化構造}

日本の産業連関表の詳細性を生かしつつ、輸入品の利用 に伴い国外で発生する環境負荷を含めた内包型原単位の算 定を行った先行研究として、本藤ら（1999）による「害態 反映型内包型原単位」がある。実態反映型の内包型原単位 は、主要な輸入品（主に一次資源）については国産技術仮 定を適用せず、積み上げ法で求めたLCIデー夕を充当する ことで国外環境負荷を内包する。しかしながら、積み上げ 法を段階的ハイブリッドLCA (Tiered hybrid LCA)（Suh et al. 2004）で組み合わせるため、産業連関分析法の利点 であるシステム境界の明確性を失ってしまう。

一方、筆者らの開発したGLIOは、MRIOの構造を維持 することでシステム境界の明確性を担保し、内包型原単位 に国外環境負荷を反映させる。また、その他の国（RoW） を定義しないことも特徵である。

表5にGLIOの勘定体系を示す。いま、A国を特に着目
する国（日本）とし、GLIOをA国の財やサービスに関す るLCAに適用することを目的とする。そのため、A国の 財やサービスの生産に必要とする各商品の投入量や GHG 排出量は表 1 と同じレベルで詳細に記述する。一方、B国 とC国のみ財とサービスを統合し、統合商品 $=$ 財 +サービ スとすることで、推計に必要とするデータポイントを $7 \times$ $4=28(28 \div 42 \times 100=66.6 \%)$ と表 1 より減らし、作表の コストを軽減する。この表に記載されている取引額の合計

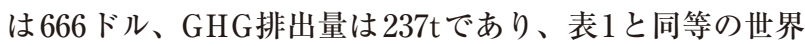
経済を表現する。最終需要の表記についても実際は工夫を 要するが、その詳細は既報（Nansai et al. 2012a）を参照 されたい。

しかし、表2、3、4と表5の違いは財とサービスの取引 の記述が正方行列であるか否かである。表2、3、4は財と サービスの取引が正方行列であるため、表 1 に基づく従来 型の産業連関分析手法が利用できる。しかし、表 5 は長方 形であるため、通常の産業連関分析手法の適用には正方化 する必要がある。B国とC国の行側の財とサービスを統合 すると、表 2 と同じになり正方化できるが、分析目的であ るA国の財とサービスの生産構造を詳細に反映した $\mathrm{GHG}$ 排出量の推計ができなくなる。そこでGLIOでは、次のよ うな工夫を行っている。

まず、B国とC 国の財とサービスの行方向の取引額を内 包型国内 $\mathrm{GHG}$ 排出量の大きさに変換する。ここで内包型 
表6 環境分析用に内包型国内 GHG 排出量基準に変換したGLIOの勘定体系(長方形)

\begin{tabular}{|c|c|cc|c|c|}
\hline \multirow{2}{*}{} & \multicolumn{2}{|c|}{ A } & B & C \\
\cline { 3 - 6 } & 財 & サービス & 統合商品 & 統合商品 \\
\hline \multirow{2}{*}{ A } & 財 $(\$)$ & 1 & 2 & 7 & 11 \\
& サービス $(\$)$ & 7 & 8 & 19 & 23 \\
\hline \multirow{2}{*}{ B } & 財 $(\mathrm{t})$ & 6.5 & 7 & 0 & 17.5 \\
& サービス $(\mathrm{t})$ & 7.6 & 8 & 0 & 18.8 \\
\hline \multirow{2}{*}{$\mathrm{C}$} & 財 $(\mathrm{t})$ & 7.5 & 7.8 & 16.5 & 0 \\
& サービス $(\mathrm{t})$ & 6.2 & 6.4 & 13.4 & 0 \\
\hline 排出 & GHG $(\mathrm{t})$ & 37 & 38 & 79 & 83 \\
\hline
\end{tabular}

表 7 環境分析用に正方化したGLIOの勘定体系

\begin{tabular}{|cc|cc|c|c|}
\hline \multirow{2}{*}{} & & \multicolumn{2}{|c|}{ A } & B & C \\
\cline { 3 - 6 } & 財 & サービス & 統合商品 & 統合商品 \\
\hline A & $\begin{array}{c}\text { 財 }(\$) \\
\text { サービス }(\$)\end{array}$ & 1 & 2 & 7 & 11 \\
\hline B & 統合商品 $(\mathrm{t})$ & 14.1 & 15 & 19 & 23 \\
\hline C & 統合商品 $(\mathrm{t})$ & 13.7 & 14.2 & 0 & 36.3 \\
\hline 排出 & GHG $(\mathrm{t})$ & 37 & 38 & 29.9 & 0 \\
\hline
\end{tabular}

国内GHG排出量とは、B国の財の生産に伴い、B国内で直 接間接に発生したGHG排出量を意味する。具体的に説明 するため、各商品の単位生産あたりの内包型国内 GHG排 出量（仮想值）を以下のように設定する。

・B国で財を 1 ドル生産すると、B国内で直接間接に $0.5 \mathrm{t}$ の $\mathrm{GHG}$ が発生する $(0.5 \mathrm{t} /$ \$)。

・B国でサービスを1ドル生産すると、B国内で直接間 接に $0.4 \mathrm{t}$ の $\mathrm{GHG}$ が発生する $(0.4 \mathrm{t} / \$)$ 。

・C国で財を 1 ドル生産すると、C国内で直接間接に $0.3 \mathrm{t}$ の $\mathrm{GHG}$ が発生する $(0.3 \mathrm{t} /$ \$)。

・C国でサービスを1ドル生産すると、C国内で直接間 接に $0.2 \mathrm{t}$ の $\mathrm{GHG}$ が発生する $(0.2 \mathrm{t} / \$)$ 。

表5ではA 国の財の生産に必要とするB国の財は 13 ドル であるが、これを内包型国内 GHG排出量で示すと、 $13 \times 0.5$ $=6.5 \mathrm{t}$ となる。また、B国のサービスは 19 ドルの投入であ るため、変換すると $19 \times 0.4=7.6 \mathrm{t}$ となる。C国についても 同様に変換すると、A国の行方向の取引はドル単位、B国 とC国の取引はton単位で示した表6のハイブリッド形式 の表を得る。表6では、必要量を示す単位は変わったが、 表 1 と同等のレベルでA国の財とサービスの生産構造を詳 細に表現し、B国とC国の財とサービスの GHG排出量の違 いが反映されている。なお、B国産業による $\mathrm{B}$ 国産品の投入、 C国産業によるC国産品の投入は中間投入に相当するため、 内包型国内 GHG 排出量に換算する場合は 0 となる（詳細
は既報（Nansai et al. 2012a）を参照）。なお、本稿では仮 想的な単位生産あたりの内包型国内 $\mathrm{GHG}$ 排出量 $(0.5 \mathrm{t} / \mathrm{S}$ 、 $0.4 \mathrm{t} / \mathrm{S} 、 0.3 \mathrm{t} / \$ 、 0.2 \mathrm{t} / \$)$ を用いたが、実用的な值はB国と C国の産業連関表、または各製品のLCIデー夕を利用する などして、それぞれ輸入品を除外した内包型原単位を求め ることで得ることができる。

最後に、表6のB国とC国の行側の財とサービスを統合し、 表7のように $\mathrm{A} 、 \mathrm{~B} 、 \mathrm{C}$ 国の取引表を正方化することで、 従来型の産業連関分析と類似の手法が適用できる。方法の 詳細については既報（Nansai et al. 2012b）を参照のこと。 $\mathrm{B}$ 国の総排出量 $79 \mathrm{t}$ と $\mathrm{B}$ 国の行方向の排出量の関係は次の ように理解できる。B国の総排出量 $79 \mathrm{t}$ は、A国への輸出 品のために $29.1 \mathrm{t}(=14.1+15)$ が排出され、C国への輸出 品のために $36.3 \mathrm{t}$ が排出された。残りの $13.6 \mathrm{t}$ ( = $79-29.1$ - 36.3）はB国の最終需要によって排出されたと解釈する。 C国の排出量も同様に理解できる。表7に基づく産業連関 分析は表4と異なり、世界全体の GHG 排出量 $237 \mathrm{t}$ も保持 される。

\section{GLIOによるグローバル環境負荷原単位の推計}

\section{1 特徴的なグローバル GHG 原単位を有する部門}

筆者らは日本経済に焦点を当てたGLIOを開発した。表 6を例にすると、A国を日本とし、財とサービスについて の部門数は406である。B国やC国に対応する国外部門と 
表 8 グローバル GHG原単位の大きい国産品上位 5 部門

\begin{tabular}{|c|c|c|c|c|c|c|}
\hline 順位 & 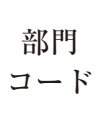 & 部門名 & $\begin{array}{c}\text { グローバル } \\
\mathrm{GHG} \text { 原単位 } \\
{\left[\mathrm{t}-\mathrm{CO}_{2} \mathrm{eq} / \text { 百万円 }\right]}\end{array}$ & $\begin{array}{l}\text { (D) 国内直接 } \\
\text { シェア [\%] }\end{array}$ & $\begin{array}{l}\text { (S) 国内間接 } \\
\text { シェア [\%] }\end{array}$ & $\begin{array}{l}\text { (F) 海外排出 } \\
\text { シェア [\%] }\end{array}$ \\
\hline 1 & JD152 & セメント & 137.7 & 92 & 6 & 2 \\
\hline 2 & JD161 & 銑鉄 & 72.6 & 84 & 6 & 10 \\
\hline 3 & JD294 & 自家発電 & 68.8 & 92 & 3 & 5 \\
\hline 4 & JD163 & 粗鋼（転炉） & 45.5 & 6 & 82 & 13 \\
\hline 5 & JD293 & 事業用電力 & 29.1 & 85 & 6 & 9 \\
\hline
\end{tabular}

表 9 グローバルGHG 原単位に占める海外排出シェアの大きい国 産品上位 5 部門

\begin{tabular}{cclc}
\hline \multirow{2}{*}{ 順位 } & $\begin{array}{c}\text { 部門 } \\
\text { コード }\end{array}$ & \multicolumn{1}{c}{ 部門名 } & \multicolumn{2}{c}{$\begin{array}{c}\text { シ } \\
\text { シェア 海外排出 }\end{array}$} \\
\hline 1 & JD183 & アルミ圧延製品 & 86 \\
2 & JD186 & その他の非鉄金属製品 & 83 \\
3 & JD72 & 飼料 & 82 \\
4 & JD56 & 植物油脂 & 76 \\
5 & JD178 & その他の非鉄金属地金 & 76 \\
\hline
\end{tabular}

して、230の国と地域を含めている。B国とC国の行方向 に定義した財とサービスは 111 種類である。整備した環境 負荷データは、エネルギー消費量（低位発熱量基準）、 GHG 排出量 $\left(\mathrm{CO}_{2} 、 \mathrm{CH}_{4} 、 \mathrm{~N}_{2} \mathrm{O} 、 \mathrm{PFCs} 、 \mathrm{HFCs} 、 \mathrm{SF}_{6}\right.$ の種 類別）および大気污染物質 $\left(\mathrm{NO}_{\mathrm{x}}\right.$ と $\left.\mathrm{SO}_{\mathrm{x}}\right)$ である。対象年 は2005年である。なお、具体的なデー夕整備方法につい ては、既報（Nansai et al. 2012b）を参照のこと。

このGLIOを用いて、日本の国産品の財とサービス（部 門コード：JD1〜 JD406）を対象に、その単位生産（百万 円相当）あたりに日本を含め全世界で発生する環境負荷量 を推計した。これを本稿では、グローバル環境負荷原単位 と称する。以下に、GHGを例として（GHGの場合はグロー バル GHG 原単位と呼称)、特徵的なグローバル環境負荷原 単位を有する日本の財・サービス部門を紹介する。

表 8 に值の大きい上位 5 部門を示す。同表では、グロー バル GHG原単位の内訳としてサプライチェーンの段階別 (D、S、F）にその寄与 (\%) を示している。ここで、D は部門の百万円分の生産に伴いその部門（国内）から直接 的に発生する GHG 排出量（国内直接）、Sは部門の百万円 分の生産に伴い国内で間接的に発生する GHG排出量（国 内間接)、そして F は部門の百万円分の生産に伴い国外で 間接的に発生するGHG排出量(海外)を意味する。「(JD152) セメント」が最も大きく、「(JD161) 銑鉄」「(JD294) 自

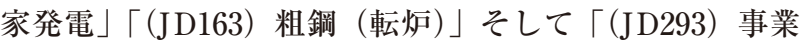
用電力」と続く。これらの部門は、 $\mathrm{D}$ と $\mathrm{S}$ の寄与が高く、 3EIDにある国内排出量のみを対象とする内包型原単位と
表 10 グローバル GHG 原単位と 3EID の国産技術仮定による内包 型原単位との乘離の大きい国産品上位5部門

\begin{tabular}{cclc}
\hline 順位 & $\begin{array}{c}\text { 部門 } \\
\text { コード }\end{array}$ & 部門名 & $\begin{array}{c}\text { 3EIDの国産技術 } \\
\text { 仮定の乘離 }[\%]\end{array}$ \\
\hline 1 & JD183 & アルミ圧延製品 & -66 \\
2 & JD11 & 種苗 & -57 \\
3 & JD47 & 製粉 & -52 \\
4 & JD90 & 製材 & -52 \\
5 & JD72 & 飼料 & -51 \\
\hline
\end{tabular}

大きな差はない。

国外でのサプライチェーンにおける排出割合（F）が高 い部門として、表 9 に上位 5 を示す。「(JD183) アルミ圧 延製品」はグローバル GHG 原単位の $86 \%$ と、日本の製品 の中で最も国外排出の割合が大きい。続いて、「(JD186) その他の非鉄金属製品」「「(JD72) 飼料」「(JD56) 植物 油脂」「(JD178) その他の非鉄金属地金」といった金属資 源関連、農作物関連の部門が上位を占めるのが特徵的で あり、国産品とは言え、GHG排出のほとんどは外国製と 言えよう。

最後に、3EIDの国産技術仮定による内包型原単位 (3EID では $\left.(\mathrm{I}-\mathrm{A})^{-1}\right)$ 型と表記）と比較する。本稿によるグロー バル内包型 GHG 原単位との乘離（\%）を（(3EIDの国産 技術仮定による内包型原単位ーグローバル内包型 $\mathrm{GHG}$ 原 単位） $\div$ グローバル内包型 GHG原単位 × 100）として計算 すると、表 10 に示す $5 つ の$ 部門が最も乘離の大きい上位 5 部門であった。3EIDの国産技術仮定を用いた場合に、最 も過小評価となるのが「(JD183) アルミ圧延製品」で $66 \%$ の違いを生む。国外排出量の割合も高く、その国外排 出量を国産技術仮定では十分に近似できない部門と言える。 次に、「(JD11) 種苗」 $(-57 \%) 、 「(\mathrm{JD} 11)$ 製粉」 $(-52 \%)$ 、 $\lceil(\mathrm{JD} 90)$ 製材」 $(-52 \%)$ 、そして「(JD72) 飼料」(-51\%) と続く。これらの差が大きい部門については、LCAの精 度向上のために国産技術仮定に基づくインベントリデー夕 を使用しないことが推奨される。 


\section{2 グローバル環境負荷原単位の入手方法}

上で紹介した日本の 406 種類の国産品に関するグローバ ル環境負荷原単位 (生産者価格基準) は3EIDのホームペー ジ (http://www.cger.nies.go.jp/publications/report/ d031/index-j.html）の「グローバル拡張」のページより無 料でダウンロードができる。環境負荷の種類は、エネル ギー消費量（低位発熱量基準）、GHG 排出量 $\left(\mathrm{CO}_{2} 、 \mathrm{CH}_{4}\right.$ 、 $\mathrm{N}_{2} \mathrm{O} 、 \mathrm{PFCs} 、 \mathrm{HFCs} 、 \mathrm{SF}_{6}$ の種類別）および大気污染物質 $\left(\mathrm{NO}_{\mathrm{x}}\right.$ と $\left.\mathrm{SO}_{\mathrm{x}}\right)$ であり、2005年を対象としている。また、 購入者価格基準に変換したグローバル環境負荷原単位も掲 載しており、用途に応じて適切にご利用いただければ幸い である。

\section{謝辞}

本研究は環境省環境研究総合推進費補助金（K122024） の支援を受けて実施された。

(平成 25 年 3 月 23 日受付)

\section{参照文献}

ディツェンバッハー E., ロス B., ティマー M. (著), 尾下優 子 (訳) (2013): 日本LCA学会誌, 9(2), 91-96

本藤祐樹, 外岡豊, 内山洋司 (1999): エネルギー・資源, 20 (1), 93-99

猪俣哲史 (2013): 日本LCA学会誌, 9(2), 67-71

中野諭, 早見均, 中村政男, 鈴木将之 (2008): 環境分析用産 業連関表とその応用, 慶應義塾大学出版会, 東京, $217 \mathrm{pp}$.

モラン D., 金本圭一朗, ゲシュク A., レンツェン M. (著), 金本圭一郎 (訳) (2013): 日本LCA学会誌, 9(2), 97-100 Nansai K., Kagawa S., Kondo Y., Suh S., Inaba R., Nakajima K. (2009): Econ. Syst. Res., 21 (3), 267-290

Nansai K., Kagawa S., Kondo Y., Suh S., Nakajima K., Inaba R., Oshita Y., Morimoto T., Kawashima K., Terakawa T., Tohno S. (2012a): Environ. Sci. Technol., 46(1), 155-163

Nansai K., Kondo Y., Kagawa S., Suh S., Nakajima K., Inaba R., Tohno S. (2012b): Environ. Sci. Technol., 46(16), 9146-9154

南斉規介, 森口祐一, 産業連関表による環境負荷原単位 データブック (3EID), 独立行政法人 国立環境研究所 地球環境研究センターホームページ, 入手先 <http:// www.cger.nies.go.jp/publications/report/d031/ index-j.html>, (参照 2013-2-1)

Suh S., Lenzen M., Treloar G. J., Hondo H., Horvath A., Huppes G., Jolliet O., Klann U., Krewitt W., Moriguchi Y., Munksgaard J., Norris G. (2004):
Environ. Sci. Technol., 38(3), 657-664

タッカーA. (著), 尾下優子（訳）（2013）：日本LCA学会誌,

9 (2), 84-90

ウォルムスリー T.L., アギアール A.H., ナラヤナン B.

(著), 金本圭一郎（訳）(2013): 日本LCA学会誌, 9 (2), 76-83

山野紀彦 (2013): 日本LCA学会誌, 9(2), 72-75

\section{編集注}

本稿は、Keisuke Nansai, Shigemi Kagawa, Yasushi Kondo, "Simplification of multi-regional input-output structure with a global system boundary: Global link input-output model (GLIO)" in: J. Murray and M. Lenzen (eds) The Sustainability Practitioner's Guide to Multi-regional Input-Output Analysis (Champaign, Illinois, Common Ground Publishing), forthcomingから 一部を抜粋し翻訳し、加筆修正したものである。 